AÜIFD Cilt XLIV (2003) Sayı 1 s. 173-186

\title{
Holocaust Problemi ve Tanrı: Teolojik ve Felsefî Cevaplar
}

\section{Muhsin AKBAŞ}

Yrd. Doç. Dr., Onsekiz Mart Üniversitesi İlâhiyat Fakültesi

e-mail:makbas@comu.edu.tr

\begin{abstract}
Holocaust Problem and God: Theological and Philosophical Answers. The destruction of Jews by the Nazis during World War II has left a great impact on Western world in general and Jewish thought in particular. The main problem here is whether this catastrophe called the Holocaust is reconcilable with the existence of God. While some Jewish thinkers find the belief in God unacceptible after the Holocaust, others seek some reasonable ways to preserve the belief in question. This article, as a first in its kind in Turkish thought, searches and evaluates the major responses to the Holocaust, which we classify in two groups as traditional and modern.
\end{abstract}

Key Words: Holocaust Problem, God, Jewish Thought

Yahudilik dünyanın yaşayan en eski kültürlerinden biridir. Aşkın, yüce varlık ya da varlıklara inancın genel adı olarak özetleyebileceğimiz klasik "din" anlayışını aşan bir kavram olarak Yahudilik, belli inanç ve ritüelleri de içeren etnik bir yapı olarak bugün de karşımızda durmaktadır. Yahudilik söz konusu olduğunda en önemli kavramlardan biri, Yahudilerin "ortak bir tarih" anlayışına sahip olmalarıdır. Bu ortak tarihin önemli bir unsuru da, 
kendilerine tarih içerisinde İbranî, Israil ve Yahudi -hatta bunlara Türkiye coğrafyasında Musevî de eklenebilir- denen insanlar ile Tanrı'nın yapmış oldugu "sözleşme"dir (İng. covenant). Bu sözleşme gereği İsrail bir Tanrı'ya inanacak, onun emir ve yasaklarma uyacak, Tanrı da buna karşlık İsrail oğullarına müreffeh bir hayat bahışedecektir. Verilen söz tutulmadı̆̆ında, İlâhî ceza beklenecektir.

Yahudiliğin geçmişte Asur, Babil ve Roma gibi büyük medeniyetler ile yolları kesişmiş ve çoğu zaman bu karşıllaşmalar beraberinde Yahudilere acı ve ıstırap getirmiştir. Asurluların M.Ö. 720'de Kuzey Krallığını (İsrail) yıkması, Babillilerin M.Ö. 587'de Güney Krallığını (Yahuda) yıkması ve sonucundaki Babil sürgünü, Yahudilerin İspanya'dan sürülmesi Yahudi tarihinde dönüm noktası niteliğindeki felaketlerden bazılarıdır. Holocaust, acı ve istırap dolu Yahudi tarihinde en son facia ve bazılarına göre de benzeri görülmemis nitelikte bir felakettir. Nazi rejiminin toplama kamplarında uyguladığı çeşitli işkencelerin sonucunda, gaz odalarında ve krematoryumlarda altı milyon Yahudi'yi imha etmesi, geleneksel Tanrı anlayışını derinden etkilemiştir. Bir çok Yahudi, her şeye gücü yeten, merhamet sahibi Tannı inancı ile Holocaust olayını uzlaştırma problemi yaşamış görünmektedir.

Aslinda bir Reform hareketi hahamı olan Richard L. Rubenstein, Holocaust'u dinî bir problem olarak ilk kez ortaya koyanlardan biridir. O, ölüm kamplarının geleneksel Yahudi Tanrı inancını iptal ettiğini iddia eder. Rubenstein, Holocaust'tan sonra Yahudilerin eskisi gibi "herşeye gücü yeten ve merhametli Tanrı'ya" inanmaya devam etmesinin mümkün olmadığını düşünmektedir.' Rubenstein'a göre Nietzche'nin "Tanrı öldü" sözü, Holocaust'u ve Holocaust sonrası dönemi anlatmak için kullanılabilecek en uygun terimdir. Çünkü Nazi mezaliminden sonra,

Tanrı ve insanı, göğü ve yeri birleştiren ip koptu. Bizler soğuk, sessiz, duygusuz kozmozda kendi kaynaklarımızın ötesindeki herhangi bir gayıli güç tarafından yardım edilmeden duruyoruz. Auschwitz'den sonra bir Yahudi Tann hakkında ne söyleyebilir? ${ }^{2}$

Yahudi teolog ve felsefeciler var oluşlarını derinden tehdit eden bu kötülük ile yüzleştiklerinde, bir çok teolojik ve felsefî açılama getirme ihtiyacı duymuşlardır. Burada yer sıkıntısı nedeni ile bu açıklamalardan bir kısmı ele alınmış ve bunlar geleneksel ve modern cevaplar olarak iki grupta tasnif edilmiştir. Geleneksel cevaplar, insanlık tarihi kadar eski olan beşen̂́ acıya dayalı kötülük problemine verilmiş klasik çözüm önerilerinin Holocaust problemine uyarlanması olarak tasvir edilebilir. Modern cevaplar ise, birtakım geleneksel dinî-tarihî motifler kullanılmakla beraber yeni

\footnotetext{
1 Richard Rubenstein ve John K. Roth, Approaches to Auschwitz: The Legacy of the Holocaust 'London: SCM Press, 1987', s. 310.

2 Rubenstein ve Roth, Approaches to Auschwitz, s. 311.
} 
kavramsal tahliller çerçevesinde Holocaust trajedesi ile Tanrı inancının uzlaştırılma çabalarından ibarettir. Bu makalede, söz konusu tartışmaları Türk okuyucularına tanıtmak amacıyla daha çok betimleyici bir anlatım tarzı benimsenmiştir. Bununla birlikte, her açıklamanın sonunda kısa bir değerlendirme yapılarak eksikliklere ve tutarsızlıklara işaret edilmiş, daha sonraki olası tartışmalara zemin hazırlanmıştır. Bu hususu da belirttikten sonra geleneksel cevaplar ile incelememize başlayabiliriz.

\section{Holocoust'a Verilen Geleneksel Cevaplar İâhî Ceza}

Kutsal Kitap ve sonraki Yahudi dinî literatüründe köklü bir geçmişi olan, acı ve ıstırapların Yahudilerin günah işleyerek Tanrı ile yaptıkları sözleşmeyi ihlal etmelerine karşıllı ilâhî bir ceza olduğu inancı, Holocaust'a verilen bir cevap olarak karşımıza çıkar. Bu inanç, klasik olarak Ibranice mipenei hata'einu -"günahlarımız yüzünden biz cezalandırıldık"- formülü ile ifade edilir. Bu görüşün daha çok geleneğe bağlı olan Ortodokslar arasında yaygın olduğu görülmektedir. Litvanyalı Talmud bilgini haham Elchanan Wasserman (1875-1941), haham Joel Teitelbaum (1888-1979), çağdaş düşünür Menachem Hartom ve Isaachar Teichthal bu görüşün en önemli temsilcileri arasindadır.

Wasserman ile Teitelbaum, bu geleneksel ilâhî ceza öğretisini Holocaust olayına uyarlayarak Tanrı'nın toplama kamplarındaki Yahudileri günahlarından dolayı cezalandırdığını iddia etmektedir. ${ }^{3}$ Wasserman ve Teitelbaum'a göre Yahudiler, babalarının inançlarından yüz çevirmişler ve bunun yerine Sosyalizm ve Siyonizm gibi kendi benliklerine yabancı düşüncelere yönelmişlerdir. Kurtuluşu Yahudi geleneğinden başka bir yerde aramak, Tanrı ile yapılan "sözleşme"ye uymamak demektir ve Tanrı da bu suçu cezalandırmıştır. Teitelbaum'un Talmud'dan dayanağ ${ }_{1}$ şudur: "Yahudiler Tanrı onları kurtarıncaya kadar sürgünde sabırla bekleyeceklerine söz verdiler." Dolayısıyla Yahudi tarihinin tabii seyrini bozan Siyonist davranışlarla bu sözleşmenin bozulması, beraberinde ilâhî cezayı getirmiştir. Oysa Yahudiler, Teitelbaum'a göre, İsrailoğullarını süregelen acıdan kurtaracak ve vaad edilmiş ebedî Israil devletini kuracak Mesih'i beklemeliydiler.

Diger taraftan İsrailli düşünürler Menachem Hartom ${ }^{5}$ ve Isaachar Teichthal, ${ }^{6}$ Wasserman ve Teitelbaum'un aksine, Holocaust'un Yahudilerin anti-siyonist tutumlarının bir cezası olduğunu iddia etmektedirler. Hartom,

3 Jonathan Sacks, Crisis and Covenant: Jewish Thought After the Holocaust 'Manchester: Manchester University Press, 1992' s. 29, 31.

${ }^{4}$ Sacks, Crisis and Covenant, s. 31.

5 Sacks, Crisis and Covenant, s. 31.

- Steven T. Katz, “The Holocaust: Jewish Theological Responses," Mircea Eliade (Ed.), The Encyclopedia of Religion, C. 6, New York: Macmillan 1987, s. 427. 
Yahudilerin tarih boyunca vaad edilmiş topraklarda olmamayı sürgünde olma, sürgünü de cezalandırma olarak kabul ettiklerini iddia eder. Oysa II. Dünya Savaşı'ndan önce Avrupa'da bulunan Yahudiler, ilk kez kendilerinin Avrupa'ya ait olduklarını düşünmüşler ve sürgünde olduklarını unutmuşlardı. Böylece onlar, bu iddiaya göre, İsrail toprağına dönme düşüncesini terketmiş ve onun yerine kendilerine başka vatan bulmuşlardı. Bunun sonucunda Yahudiler, anti-siyonist tavırlarına karşılık ceza olarak acı çekmişler ve Avrupa II. Dünya Savaşı sırasında öldürülen altı milyon Yahudiye mezar olmuştur.?

Holocaust'u dinî bir problem clarak ele alan ve ona çözümler getirmeye çalışan Yahudi teolog ve felsefecilerinin büyük bir kısmı, cezalandırıcı açıklamayı kabul etmemektedir. Örneğin Britanya Hahambaşı Jonathan Sacks, bu görüşü şu ifadelerle eleştiłmektedir:

Ölenlerin yüzde 90'ı, geleneksel Yahudi dindarlığının hayatta kalan son kalesi olan Doğu Avrupa Yahudilerindendi. Ölüm makineleri bilge, aziz ayırımı yapmaksızın hayatlarını inanca adamış kişileri yok etti. Bir milyondan fazla çocuk gazla zehirlendi, yakıldı, vuruldu, işkence yapıldı veya canlı canlı toprağa gömüldü. ${ }^{8}$

Ölüm kamplarındaki alevlerin çocuk-yaşlı, dindar-dinsiz demeden Yahudileri yok etmesi, Holocaust'un ilâhî bir ceza olduğu görüşüne karşı ciddî bir itiraz olarak görülebilir. Tanrı'nın yetişkinleri günahlarından dolayı cezalandırdığı var sayılsa bile, bu cevap suçsuzların ölümünü açiklamaktan uzak görünmektedir. Ayrıca bu felaketin ilâhî bir ceza olduğunu öne sürenler, iddialarını doğrulayacak kesin bir kanıttan da yoksun görünüyorlar. Holocaust'un ilâhî ceza olduğunu söyleme hakkı, eğer öyle ise, Tanri'dan başka kimsede olmasa gerektir.

\section{Hür İrade Savunması}

Ortodoks teolog Eliezer Berkovits, Faith After the Holocaust (Holocaust'dan Sonra Inanç) başlıkli kitabında Holocaust'u açıklamaya çalışır. Berkovits'in cevap aradığı soru, "Holocaust sırasında Tanrı'nın korkunç sessizliği karşısında inanç ifadelerinin anlamlı olup olamayacağına ilişkindir."” Berkovits, getirdiği açıklamanın Tanrı'nın İsrail ile olan ilişkisini haklı çıkarma teşebbüsü olarak görülmemesi gerektiğini, ancak bunun toplama kamplarının dehşetinden sonra inanca bir yer bulmak için "Tanrı ile yüzleşme" ("reasoning with God") oldugunu öne sürer. Berkovits'e göre, böyle bir felaket karşısında "Tanrı ile yüzleşme inanç

7 Katz, "The Holocaust: Jewish Theological Responses," s. 427.

${ }^{8}$ Sacks, Crisis and Covenant, s. 32.

${ }^{9}$ Eliezer Berkovits, Faith After the Holocaust, New York: KTAV Publishing House Inc., 1973, s. 85 . 
gereğidir."10 Bu şekilde Tanrı'nın esrarengiz yolları ortaya konabilir ve huzur bulunabilir.

Berkovits, bir kişinin hür ve davranışlarından dolayı sorumlu olması için, "Tanrı'nın kendisinin tarihte bulunmaması"ll gerektiğine inanmakta ve Yahudi geleneğindeki "Tanrı'nın yüzünü gizlemesi" kavramını, insanın hür olmasına imkân sağlayan zorunlu ilâhî bir sıfat olarak açıklamaktadır. Eğer "insan" insan olacaksa, Tanrı ona seçme hürriyeti vermelidir. Bunun için de Tanrı'nın kendisini gizlemesi gerekir. İsan sadece bu yolla hürriyetini kullanabilir ve var olmaya devam edebilir. Hür iradenin varlığı ise, insana iyilik ve kötülük yapma imkânı verir. Berkovits, hürriyet ve sorumluluk olmaksızın kimsenin insanların varlığından söz edemeyeceğini iddia eder. Bir kişinin seçme hürriyetini kötüye kullanması ve yanlış tercihte bulunması durumunda, masum olanın acısı veya kötünün mutluluğu ortaya çıkabilir.

Berkovits'e göre Kutsal Kitap, "Tanrı'nın yüzünü gizlemesinden" (Ibranice Hester Panim) iki farklı anlamda bahseder. Tesniye 31:17-18'de "yüzün gizlenmesi," putperestlerin Tanrı tarafından cezalandırılması anlamına gelir. Tanrı'nın onlardan yüzünü gizleyeceği, onların kolay av olacağı ve onlara birçok korkunç felaketlerin geleceği anlatılır. Diğer taraftan Mezmur yazanı, düşmanları Yahudileri acı ve ıstıraba maruz bırakırken Tanrı'nın sessiz kalmasından şikayet eder: "Uyan, niçin uyuyorsun, ya RAB? Kalk, bizi ebediyen bırakma. Niçin yüzünü örtüyorsun, ve düşkünlüğümüzü, mağdur olduğumuzu unutuyorsun?" (Mezmur 44:2324). Berkovits, ilk örnekte Tanrı'nın yüzünü gizlemesinin ilâhî cezalandırma anlamına gelebilecekken, ikinci durumda acı çeken insanların yalvarmasına Tanrı'nın sessiz kalması görünüşte herhangi bir nedenden dolayı değildir. Talmud bilgelerinin "yüzün gizlenmesi," yani, Tanrı'nın tarihte yokluğu, kavramından anladığı şey, daha çok ikinci türdendir.

Berkovits, bir tür "sınırlı Tanrı" anlayışı benimseyerek ilâhî kudretin tarih sahnesinde faaliyette olduğunu düşünmenin imkânsız olduğunu iddia eder. Eğer Tanrı fizikî gücünü dünyada sürekli olarak kullansaydı, insanın varlığı mümkün olmazdı. Ancak Berkovits, Mısır'dan Çıkış hikayesinde olduğu gibi tarihte Tanrı'nın maddî gücünü kullandığı bazı durumların olduğuna da inanır. Böyle durumlarda ilâhî müdahaleden, başka bir deyişle mucizeden, söz edilir; Berkovits'e göre "mucize ise tarihin dışındadır."।2 Bununla beraber Talmud bilgeleri ilâhî kudreti, Tanrı'nın kötüyü hemen yargılamaktan ve cezalandırmaktan geri durması anlamında almışlardır. Onlara göre gerçek kudret, düşmanlarını hemen imha edebilecekken güç kullanmaktan vazgeçebilmektir. Bu anlamda, kullanılmayan kudret kudrettir.

Berkovits, ölüm kamplarındaki Yahudilerin başlarına gelenlerin Yahudi tarihinin tamamıymış gibi davranarak Holocaust nedeniyle Yahudi inancını

\footnotetext{
${ }^{30}$ Berkovits, Faith After the Holocaust, s. 68.

"Berkovits, Faith After the Holocaust, s. 107.

${ }^{12}$ Berkovits, Faith After the Holocaust, s. 109.
} 
yargılamanın doğru olmadı̆̆ını iddia eder. Holocaust, bütün İsrail tarihinden sadece bir kesittir. Holocaust karşısında geçmiş, şimdi ve gelecek görmezden gelinemez. Berkovits'e göre Holocaust, "Yüzün Gizlenmesinin" bir örneği olmasına karşın, Mısır'dan Çıkış, Babil sürgününden dönüş, geçmişte yaşamış diğerleri yanında peygamberlerin sözleri, inançlı Yahudiler tarafından tarihte ilâhî varlığın örnekleri olarak tanınır. ${ }^{13}$ Sadece Holocaust nedeniyle, Yahudi inancı ve Tanrı'nın tarihte varlığı inkâr edilemez. Berkovits'e göre, Nazilerin "Kesin Çözüm" planının başarısızlığı, Yahudilerin Nazi zulmünden kurtulmaları ve modern İsrail devletinin kurulması, Tanrı'nın varlığını tarihte bulunmadığında bile bilmeye imkân vermektedir. Ancak Berkovits, açıklamasının Tanrı'nın suçsuzların acı çekmesine izin vermesini haklı göstermediğini kabul eder.

Berkovits'in hür irade açıklaması bir noktaya kadar Holocaust'u beşerî iradenin kötüye kullanılması anlamında açıklamada başarılı görünse de, Tanrı'nın tarihin belirli zamanlarında müdahale edip toplama kamplarında etmemesi noktasında birşey söylememektedir. Mısır'dan kaçarken Yahudileri Kızıl Deniz'de boğulmaktan kurtaran Tanrı, neden dolayı onları toplama kamplarında, gaz odalarında ve krematoryumlarda yalnız bırakmıştır? Nazilerin huzurunda ölümün soğuk nefesini her an hisseden bir topluluk, en çok ihtiyaç duyduğu anda kurtarıcısını yanında göremediğinde, Tanrı'yı inkâr etmesine ne mani olacaktır? Görünüşe göre Berkovits, bu soruları yanıtsız bırakmaktadır.

\section{Eskatolojik Çözüm}

Çağdaş Yahudi felsefeci Dan Cohn-Sherbok God and the Holocaust (Tanrl ve Holocaust) adlı kitabında, Holocaust problemine geleneksel bir cevap önerir. Cohn-Sherbok, Yahudi ölümsüzlük inancının Tanrı inancı ile modern felaketi uzlaştırdığını iddia eder. Dahası o, eskatolojik çözümün gelecekte "dinî inancın dayanak noktası olarak hizmet edecek"14 tek alternatif olduğunu ileri sürer. Lehinde felsefi, ahlâki ve psikolojik deliller de ileri sürüldügüu, dinî anlamda rabbanî öğretilere dayanan eskatolojik açıklama, Cohn-Sherbok'a göre, "Tanrı'nın yollarını açıklamak için ciddî bir girişimdir." ${ }^{15}$

Kutsal Kitap'ta Tanrı, "sözleşme"yi koruyan İsrailoğulları için mükafat, karşı çıkanlar için de ceza vaad etmiştir. Illk hahamlar bu vaadin dünyada her zaman gerçekleşmediğini gördüklerinde, gerçekleşeceğini düşündükleri ölümden sonra bir hayatın varlığı inancına yönelmişlerdir. Onlar, Tanrı'nın bütün insanların gerçek ilâha ibadet ettiği Mesih çağında, seçilmiş milletini bir bütün olarak ve tek tek temize çıkaracağına inandılar. Israil'in

${ }^{13}$ Berkovits, Faith After the Holocaust, s. 134.

it Dan Cohn-Shcrbok, God and the Holocaust (Leominster, Herefordshire: Gracewing, 1996), s. 129.

is Cohn-Sherbok, God and the Holocaust, s. 121. 
düşmanlarının gücü imha edilecek, her Yahudi düşmanları üzerindeki kesin zaferi tatmak için diriltilecekti. Bu geleneksel öğreti, felaketler karşısında Yahudilere yüzyıllar boyu önemli bir güven duygusu vermiştir.

Cohn-Sherbok aynı zamanda, Nazi toplama kamplarındaki birçok dindar Yahudinin acılarının ve ölümlerinin "daha muhteşem bir geleceğin başlangıcı" olduğuna inandıklarını iddia eder. ${ }^{16}$ Onlar için hayat, doğum ve ölüm arasındaki kısa bir süre değildi. Onlar, Tanrı'nın kendilerini bu dünyadaki erdemliliklerinden dolayı ödüllendireceği gelecek dünyanın varlığına inanıyorlardı. Cohn-Sherbok'a göre, toplama kamplarındaki Kiddus haŞem ("ilâhî adın kutsanması") ritüelinin" ve "Mesihçi kurtuluş" inancının arkasındaki motif buydu. Hayatta kalan Yahudilerin şahitliklerinin gösterdiği gibi, ölüm kamplarındaki Yahudiler, Tanrı'nın adını kutsayarak gelen ölümlerinin geride kalan Yahudilere bağışlama getireceğine inanıorlard. Toplama kamplarındaki Yahudilerin bir kısmı yaşanan acıların ve ölümlerin, uzun süredir beklenmekte olan Mesih'in ayak sesleri olduğuna inanıyorlardı. ${ }^{18}$ Dindar Yahudiler, toplama kamplarının ve gaz odalarının ötesinde ebedî mutluluğa ulaşacakları gerçek hayatın varlığından oldukça emindiler. Cohn-Sherbok'a göre, ölümsüzlük düşüncesi Yahudilerin Tanrı inancinı muhafaza etmelerinin tek yoludur.

Ancak modern Yahudilikteki Yeniden Yapılanmacı hareketin kurucusu Mordecai M. Kaplan (1881-1983), ölümden sonraki hayat inancının kötülük problemi ile yüz yüze gelen günümüz insanı için artık geçerli bir cevap olmadığını iddia eder. Kaplan gelenekte ahiret inancının söz konusu probleme bir cevap olarak verildiğini kabul etmekle beraber, aynı şeyin bugün için söz konusu olamayacağını öne sürer. Yahudi düşünür bu görüşünü şöyle açıklıyor:

Modern insanlar, ahirette telafi edilmesi için neden bu dünyada acı çekmemiz gerektiğini anlayamıyorlar. Nazilerin altı milyon Yahudiye karşı işlediği mezalim ve Nazi, Faşist ve Komunist baskıları ile her iki tarafın orduları tarafından son savaşlarda birçok başka insana verilen benzer istırap, ölüm sonrası hiçbir ödülün karşılayamayacağı veya açıklayamayacağı boyuttaki bir trajediyi oluşturur..$^{19}$

Kaplan'a göre sadece ölüm sonrası hayat değil, Yahudi dinî geleneği söz konusu problemi tatmin edici şekilde açıklayacak bir cevaba sahip değildir. Bu nedenle de, yeni bir Tanrı kavramının geliştirilmesine acilen ihtiyaç vardır.

\footnotetext{
${ }^{16}$ Cohn-Sherbok, God and the Holocaust, s. 126.

${ }^{17}$ Cohn-Sherbok, God and the Holocaust, s. 125.

${ }^{18}$ Cohn-Sherbok, God and the Holocaust, s. 126.

${ }^{19}$ Mordecai M. Kaplan, "The Principles of Reconstructionism and Some Questions Jews Ask," Nahum N. Glatzer (Ed.), Modern Jewish Thought: A Source Reader, New York: Schocken Books 1977, s. 153.
} 
Kaplan'ın ölüm sonrasına ilişkiı açıklamaları hakkında iki konuya itiraz edilebilir. Bunlardan birincisi, Holocaust'a cevap olarak verilen ölüm sonrası hayat inancı, insanların öldükten sonna ödüllendirilmeleri için bu dünyada acı çekmeleri gerektiğini söylemiyor. Buradaki temel iddia, dünya hayatının hür varlıklara ait olduğu ve ilâhî adaletin öteki hayatta cereyan edeceği şeklindedir. Ikinci itiraz da Kaplan'ın açıklamalarının pratik sonucuna ilişkindir. Nazi yıkımının çok büyük olduğu, Kaplan da dâhil olmak üzere pek çoklarınca kabul edilmiştir. Ancak "ölümden sonra hiçbir ödül bunları açıklayamaz veya telafi edemez" demek, acı çeken herkesin ve özellikle Holocaust kurbanlarının bütün umutlarını yok edecektir. Ölümsüzlük inancını barındırmayan bir açıklamanın, önemli bir eksiklik içerdiği kanaatindeyiz.

\section{Holocaust'a Verilen Modern Cevaplar \\ Yeni Bir Vahiy}

Çağdaş Yahudi felsefeci Emil Ludwig Fackenheim (1916-...), modern felaketin sadece Yahudiliğe karşı değil aynı zamanda Hristiyanlık ve felsefeye karşı da eşsiz ve "en radikal karşı delil" oluşturduğunu düşünür..$^{20}$ Fackenheim, Holocaust için "gaye arama" ile "cevap arama" çabaları arasında fark olduğuna inanır. O öncekinin küfür, sonrakinin ise kaçınılmaz olduğunu düşünür. ${ }^{21}$ Bundan dolayı Fackenheim, "günahlarımızdan dolayı cezalandırılıyoruz" şeklinde formüle edilen geleneksel cevabı ve Holocaust'ta bir gaye olduğu görüşünü reddeder: "Auschwitz'de dinî veya lâ dinî hiçbir gaye bulunamaz."22 Holocaust problemiyle yüz yüze gelirken Fackenheim, Yahudilerin Hitler'in zaferini tamamlamasına engel olmak için inançlanına sahip çıkmaları gerektị̌̌ini iddia eder.

Fackenheim, Tanrı'nın Yahudi tarihi boyunca meydana gelmiş önemli olaylarda var olduğunu iddia eder. Bu tarihî olaylar, Yahudi hayatının geleceği üzerinde önemli etkileri olmuş "temel tecrübelerdir" (İng. "root experiences"). Yahudiler, Mısır'dan Çıkış sırasında Kızıl Deniz'de Tanrı'nın "kurtaran varlığını" (İng. saving presence) ve Tora'nın vahyedildiği Sina Dağı'nda onun "emreden varlığını" (İng. commanding presence) tecrübe etmişlerdir. "Temel tecrübelerin" ụ̧̈ bariz özelliği vardır. Birincisi, olayın vuku bulduğu esnada ilâhî varlık tanıklar tarafından hemen kabul edilir. Ikincisi, söz konusu olay insanlara açıktır ve çok önemlidir. Üçüncüsü, olayı

${ }^{20}$ Fackenheim bu iddiasını, alı milyon Yahudi'nin ölümü ile bir çocuğun kanserden ölümü arasında kötülük problemi olması açısından bir fark görmeyen, Holocaust'un eşsizliğini inkâr eden Yahudi ve Hristiyan düşünïrler ile felsefecilere karşı yöneltmiştir. Bk. Emil L. Fackenheim. To Mend the World: Foundations of Post-Holocaust Jewish Thought, Bloomington and Indianapolis: Indiana University Press, 1994, s. 11.

${ }^{21}$ Emil L. Fackenheim, The Jewish Return into History: Reflections in the Age of Auschwitz and a New Jerusalem, New York: Schocken Books, 1978, s. 29.

22 Fackenheim, The Jewish Return into History, s. 29. 
"daha sonraki nesiller anlayabilir."23 Kısaca, "temel tecrübeler" sadece geçmiş olaylar olmayıp aynı zamanda şu anda Tanrı'nın kurtaran eylemine inanc1 gösterirler.

Dahası Fackenheim, Yahudi tarihinde İsrail'in "temel tecrübelerine" meydan okuyan bazı önemli buhranlar olduğunu da iddia eder. Fackenheim bunları, "çığır açan olaylar" (İng. "epoch-making events") olarak adlandırır. ${ }^{24}$ Diğerleri yanında, İlk Tapınağın Babilliler, Ikincisinin Romalılar tarafından yıkılması, tarihteki ilâhî varlığı test eden "çığır açan olaylardı." Bu meydan okumalara cevap olarak peygamberler ve Talmud bilgeleri, insanlar1 Tanrı'nın kurtarıcı varlığına inançlarını korumaya çağırmıştır. ${ }^{25}$ İsrail, tarihte meydana gelmiş bütün bu feci olaylardan sonra Tanrı'nın kurtaran ve emreden varlığına inancını korumaya muvaffak olmuştur.

Fackenheim, toplama kamplarında Tanrı'nın varlığına meydan okuma özelliği nedeniyle Holocaust'un "çı̆̆ır açan bir olay" olduğunu iddia eder. Ancak o, Holocaust'a bir tepki olarak Tanrı inancının terkedilmesinin doğru bir davranış olmadığına inanır. Toplama kamplarında "kurtarıcı ses" olmamakla beraber, Fackenheim "emreden sesin" işitildiğinde ısrar eder. Bu "emreden ses," yeni bir vahiydir; Fackenheim bunu, "614. Emir" olarak tanımliyor. Tora'da 613. emir (İbranice Mitzva) bulunurken, Tanrı toplama kamplarında yeni bir emir vahyetmiştir. Fackenheim bu 614. Emri şöyle ifade ediyor:

Yahudiler, ölüm sonrası zaferler sunmaktan men edilirler. Onlara, Yahudilerin yok olmaması için Yahudi olarak hayatta kalmaları emredilir. Onlara, hatıralarının yok olmaması için Auschwitz kurbanlarını hatırlamaları emredilir. Onların, Auschwitz kuvvetlerine dünyayı teslim etmede işbirliği yapmamaları için insanoğlundan ve bu dünyadan umutsuzluğa düşmeleri ve kinizme [cynicism] veya öteki dünya işlerine dalarak kaçmaları yasaklanmıştır. Son olarak, Yahudilik yok olmasın diye onların İsrail'in Tanrı'sından ümitlerini kesmeleri yasaklanmıştır. $^{26}$

Bunlar, Holocaust sonrası dönemde Yahudilerin kutsal görevleridir. Fackenheim'in bu yorumu, Holocaust'a verilen cevapların en etkililerinden biri olmuştur.

Öyle görünüyor ki, Fackenheim Holocaust için geliştirdiği açıklamasını doğrulamadan öylece bırakmıştır. Holocaust gerçekten Yahudiler için yeni bir vahiy midir? Cohn-Sherbok'un da dediği gibi, Fackenheim "Auschwitz'in

\footnotetext{
${ }^{23}$ Cohn-Sherbok, God and the Holocaust, s. 45.

${ }^{24}$ Emil L. Fackenheim, God's Presence in History: Jewish Affirmations and Philosophical Reflections (New York: Harper and Row, 1972), s. 16.

${ }^{25}$ Fackenheim, God's Presence in History, s. 25-31.

${ }^{26}$ Emil L. Fackenheim, "The Voice of Auschwitz," Nahum N. Glatzer (Ed.), Modern Jewish Thought: A Source Reader, New York: Schocken Books, 1977, s. 188.
} 
yirminci yüzyıl Yahudileri için Tora'ya dayanan bir vahiy olayı" olduğu iddiasını doğrulamaya teşebbüs etmez. ${ }^{27}$ Önemli miktarda Yahudi Tanrı inancını reddetmekle beraber, Fackenheim görüşünü akılcı bir şekilde açıklamaya çalışmaz. Yahudilerin Holocaust'tan sonra hayatta kalmasının nedeni, Fackenheim'ın dediği gibi yeni bir vahiy değil de her insanın tabiatında bulunan ve en temel içgüdülerden olan hayatta kalma içgüdüsü de olabilir.

Eğer Fackenheim'ın görüşünü kabul edecek olursak, bazı problemler ortaya çıkacaktır. Bunlardan ilki, Tanrı iyiyi de kötüyü de yaratır demek bir şey, kötülük onun vahyidir demek başka bir şeydir. Vahyetmesi gereken şeyi Tanrı, iyi bir vahiyle bildiremez miydi? Bu kadar çok insanın ölmesi gerekli miydi? Ayrıca Holocaust'un vahiy olduğunu kim ıspatlayabilir? Yoksa bu Fackenheim'ın kuruntusu mudur? Fackenheim bize bu soruların cevaplarını vermemektedir.

\section{Tremendum}

Holocaust'a verilen diğer bir önemli teolojik cevap, Yahudi teolog Arthur A. Cohen'den geliyor. Ölüm kamplarına cevap olarak o The Tremendum: A Theological Interpretation of the Holocaust (Tremendum: Holocaust'un Teolojik Bir Yorumu) adlı kitabında, hür irade savunmasının bir versiyonu ile birleştirilmiş Yahudi Tanrı kavramının yeni bir yorumunu takdim eder. Cohen, Nazi terörünün kötülüğünün büyüklügü bakımından eşsiz olduğu için, geleneksel Tanrı kavramının yeniden ele alınmasını gerektirdiğini iddia etmekte ve bu bağlamda yeni bir teoloji geliştirmeye teşebbüs etmektedir.

Alman Protestan teolog Rudolf Otto (1869-1937) tarafından ortaya atılan ve Tanrı'nın kutsallığı anlamına gelen "mysterium tremendum" kavramından esinlenen Cohen, Holocaust'u anlamak için "tremendum" terimini benimser. Otto'nun The Idea of the Holy (Kutsal Düsüncesi) başlıklı kitabında geliştirdiği Kutsal (İng. Holy) fenomenolojisine göre mysterium tremendum, ibadet eden kişi tarafından ilâhî varlığın tefekkürü sırasında tecrübe edilen derin ve nüfuz. edilemeyen muammadır. ${ }^{28}$ Cohen'in argümanında ise, tremendum felaketin "enginliğini" ifade etmektedir. Cohen şöyle ifade etmektedir: "Ben ölüm kampların tremendum olarak adlandırıyorum; çünkü o, hayata bağlı hiçbir kimsenin hayal edemeyeceği ve benzeri olmayan psiko-seksüel ve patalojik yozlaşmanın, ölümün çılgınca

${ }^{27}$ Dan Cohn-Sherbok, "God and the Holocaust," Dan Cohn-Sherbok (Ed.), Theodicy, Lampeter: The Edwin Mellen Press, 1997, s. 89.

${ }^{2 *}$ Rudolf Otto, The Idea of the Holy: An Inquiry into the Non-Rational Factor in the Idea of the Divine and Its Relation to the Rational, Çev. John W. Harvey, Middlesex: Penguin Books, 1959, s. 26-55. 
kutlanmasının ve hayatın anlamsızca tersine dönüşünün anıtıdır." ${ }^{29} \mathrm{Bu}$ bağlamda, Avrupa Yahudiliğinin Naziler tarafından imha edilmesi, Cohen'e göre, anlamı reddeden eşsiz "beşerî tremendum"dur.

Cohen'e göre tremendum, tarihteki diğer felaketler ile karşılaştırılamaz ve eşsizdir. Bundan dolayı, Tapınakların yıkılması ve Yahudilerin İspanya'dan sürülmesi gibi eski felaketlere verilen geleneksel cevaplar, tremendum için artık yeterli değildir. Bunun nedeni, "merhametli ve koruyan bir Tanrı, seçilmiş milletinin yok olma sınırlarına getirilmesine izin vermiş görünmektedir." ${ }^{30}$ Eğer o, geleneksel görüuşün kabul ettiği gibi koruyan bir Tanrı idiyse, Yahudiler gaz odalarında öldürülürken Tanrı'nın sessiz kalması nasıl mümkün olmuş olabilir? Cohen cevap olarak geleneksel Tanrı kavramının tekrar gözden geçirilmesini ve yeni bir teoloji oluşturulmasını önerir. Bu yapıcı teoloji, ilk olarak, kötülüğün gerçekliğini inkâr etmeden evrende Tanrı'nın varlığını kabul etmelidir. İkinci olarak, Tanrı'nın dünya ile ilişkisini, ondaki "şeytanî yapı" da dâhil olmak üzere, anlamlı ve önemli görmelidir. Son olarak, Tanrı'nın zatını onun dünya ile ilişkisinden ayırmamalıdır. Cohen, bu özelliklerin herhangi biri inkâr efilecek olursa, yaratma ve Tanrı'nın açıklanamayan şeyler için sadece bir metafor olduğunu iddia eder. ${ }^{31}$

Cohen, iki teolojik geleneği bir araya getirerek yukarıda ana hatları çizilen teolojisini formüle etmeye çalışır. Bunlar, "kabbalist Yahudiliğin karşı tarih yorumu" ve "Fiore'li Joachim'den Schelling'e ondan Franz Rosenzweig'a ulaşan bir gelenektir. ${ }^{.32}$ Cohen, kabbalist Tanrı doktrinini (Ibranice Ein Sof) ve onun dünya ile ilgisini, mutlaklığı ve zorunluluğu nedeniyle Tanrı'nın varlığının pasif olması şeklinde tanımlar. Bir zamanlar o, dileyecek hiçbir araca ve yaratacak hiçbir gerçekliğe sahip değildi. Sonradan Tanrı'nın varlığı "yokluğun kıvılcımı," yani, diğerlik durumu, tarafından aktif hâle geçirildi. ${ }^{33}$ Ayrıca Cohen, Schellingçi iki kutuplu Tanrı görüşüne başvurur. Bunun anlamı, Tanrı'nın içinde iki yön vardır: Tanrı'nın aslî "kendiliği" ve kişiliği bir tarafta, "zengin ve taşkın" yönü diğer tarafta. Cohen bunun, "zorunluluk ve hürriyet,...dünyanın yeterli hiçliği ve varlığın yaratılması arasındaki diyalektiğin" kaynağı olduğunu iddia eder. ${ }^{34}$ Böylece Tanrı bir yönüyle gizli, diğer yönüyle açığa vuran varlıktır.

\footnotetext{
${ }^{29}$ Arthur A. Cohen, The Tremendum: A Theological Interpretation of the Holocaust, New York: The Crossroad Publishing Company, 1981, s. 19.

${ }^{30}$ Cohen, The Tremendum. s. 50-1.

${ }^{31}$ Cohen, The Tremendum, s. 86.

${ }^{32}$ Cohen, The Tremendum, s. 86-8.

${ }^{33}$ Cohen, The Tremendum, s. 86.

${ }^{34}$ Cohen. The Tremendum, s. 89.
} 
Yahudi teolog Steven Katz'ın işaret ettiği gibi, ${ }^{35}$ Cohen bu iki görüşün sentezinden birtakım sonuçlara ulaşır. Birincisi, Tanrı zorunlu pasif, gizli, bir yöne sahiptir. İkincisi, Tanrı'nır sevgisi yaratmayı meydana getirir. Üçüncüsü, Tanrı'nın taşan tabiatı insan hürriyetini gerektirir. Son olarak da, Cohen'in kelimeleri ile ifade edecìk olursak, "İlâhî hakikat tabiatında ve açığa vurmasında çift kutupludur." ${ }^{36}$ O'nun açısından Tanrı'nın tabiatı, bizim açımızdan O'nun zenginliğ́idir. Âlem, evrendeki varlıklar ve olaylar, aynı zamanda Tanrı'ın sonsuz tabiatının içindedir. Âlem Tanrı'nın içinde zorunlu olduğu için, hürriyet ve akıl sahibi insanların yaratılması ile tamamlanmıştır.

Cohen bu noktada, çift kutuplu Tanrı kavramı ile yakından bağlantılı olan kendi hür irade savunmasırı takdim eder. Cohen, hür insanların varlığının Tanrı'nın taşan tabiatının tabii bir sonucu olduğunu iddia eder. Bundan dolayı insanlık, iyi veya kötü nasıl isterse öyle davranmakta hürdür. Cohen şöyle açıklıyor:

İnsanda sonluluğumuz tarafından tehdit eder hâle gelmiş ve oranı artmış sürekli bir mücadele ve gerilim vardır; bunlar akıl tarafından işaretlendiğinde ve kapsandığında hürriyet artar, ancak akıl ifade tarzı bulmakta başarısız olduğunda hürriyet yıkıcı bir şekilde baskıdan kırtulur ve yalana doğru eğrilir veya tamamıyla kötü niyete yenik düşer. ${ }^{37}$

$\mathrm{Bu}$ anlamda düzensizlikleri ve kötülükleri ile beşen̂ tarih, insan hürriyetinin ürünüdür, ilâhî takdirin değil. Eğer tarih, Yahudi geleneğinin iddia ettiği gibi, Tanrı'nın kendi ese-i ise, Cohen soruyor, "Tanrı'nın Holocausta şahit olup da sessiz kalması nasıl mümkün olabilir..."38 Tanrı Nazilerin planlarını niçin boşa çıkarmadı ve Yahudi tarihinde birçok kez yaptı̆̆ı gibi toplama kamplarındaki Yahudileri kurtarmadı? Cohen'e göre "Tanrı, bizim tarihî ve özel durumumuzun stratejisti değil, ancak geleceğimizin muamması, daima bizim kuvvemizdir asla davranışlarımız değildir." 39 Tarihî olan beşerî hürriyet alanı içerisinde olmasına rağmen, Tanrı tarihî olana tamamen ilgisiz de değildir. Cohen ilâhî hayatı, tarihin imalı ve üssel önemini emniyet altına alan" tarihî olanın içindeki "filaman" olarak anlar. ${ }^{40} \mathrm{O}$ zaman şeytanî olanı temsil eden tremendum, ilâhî filamana beşerî engeli ifade eder. Bundan dolayı Cohen'in düşüncesinde iyi veya kötü tarihî olaylar, Yahudi geleneğinin müdahaleci olarak düşündügü Tanrı'nın değil, insanların hürriyetinin tabii sonucudur. Sonuç olarak, hür insan

\footnotetext{
${ }^{35}$ Steven T. Katz, "The Shoah," Danicl H. Frank ve Oliver Leamen (Ed.), History of Jewish Philosophy, C. 2, London: Routledge, 1997, s. 860.

${ }^{36}$ Cohen, The Tremendum, s. 91.

${ }^{37}$ Cohen, The Tremendum, s. 92.

${ }_{3 *}^{3 *}$ Cohen, The Tremendum, s. 95.

${ }^{39}$ Cohen, The Tremendum, s. 97.

"Cohen. The Tremendum, s. 97-8.
} 
iradesinin kötüye kullanılması Holocaust'un nedenidir. Bu nedenle, ölüm kamplarında işlenen suçların sorumlusu Tanrı değil, insanlardır.

Cohen'in açıklaması ve onun vazgeçilmez bölümü olan Tanrı kavramı, geleneksel Yahudi düşüncesi ile tutarlı mıdır? Cohn-Sherbok'a göre Cohen, geleneksel Yahudiliğin temel bir kısmını, yani, tarihin içinde ve dışında olan tarihî Tanrı doktrinini görmezden geldi ${ }^{41}$ İsrail'i Misır sürgününden mucizevî bir şekilde kurtaran odur. Geleneksel Yahudi Tanrısı yaratır, korur ve beşer âlemine müdahale eder. Öyle görünüyor ki, Cohen geleneksel monoteistik Tanrı kavramını deistik bir Tanrı anlayışıyla değiştirirken, belki de farkında olmadan mevcut problemlerden daha ciddî olanlarına neden olmuştur.

Sonuç olarak, Holocaust'u açıklamak için öne sürülmüş bu cevapları incelediğimizde, bunların böyle büyük bir felaketin meydana gelmesine Tanrı'nın neden izin verdiğini açıklamada yetersiz kaldığını görüyoruz. Ĕ̆er Tanrı kudretli, merhametli ve adil ise, altı milyon Yahudinin, kendi seçtiği insanların, yok edilmesine neden göz yummuştur? Günahkar-günahsız, inanan-inanmayan ayrımı olmadan korkunç sayıda insanın öldürülmesi, bu olayda ilâhî gaye olduğunu açıklamaya yönelik cevapların yetersizliğini göstermektedir. Bütün bunlar, insan aklının sınırları ötesindeki bir varlığı, ve mahiyetini anlamadaki başarısızlığından başka bir şey olmasa gerektir. Bu sir perdesi kişinin ölümünden sonra aralanacak ve aranan cevaplar bulunacaktır.

\section{KAYNAKÇA}

Berkovits, Eliezer, Faith After the Holocaust, New York: KTAV Publishing House Inc. 1973.

Cohen, Arthur A., The Tremendum: A Theological Interpretation of the Holocaust, New York: The Crossroad Publishing Company, 1981.

Cohn-Sherbok, Dan, God and the Holocaust, Leominster, Herefordshire: Gracewing, 1996.

Cohn-Sherbok, Dan., "God and the Holocaust," Dan Cohn-Sherbok (Ed.), Theodicy, Lampeter: The Edwin Mellen Press, 1997.

Fackenheim, Emil L., God's Presence in History: Jewish Affirmations and Philosophical Reflections, New York: Harper and Row, 1972.

Fackenheim, Emil L., "The Voice of Auschwitz," Nahum N. Glatzer (Ed.), Modern Jewish Thought: A Source Reader, New York: Schocken Books, 1977.

Fackenheim, Emil L., The Jewish Return into History: Reflections in the Age of Auschwitz and a New Jerusalem, New York: Schocken Books, 1978.

Fackenheim, Emil L., To Mend the World: Foundations of Post-Holocaust Jewish Thought, Bloomington and Indianapolis: Indiana University Press, 1994.

${ }^{41}$ Cohn-Sherbok, "God and the Holocaust," s. 83. 
Kaplan, Mordecai M., "The Principles; of Reconstructionism and Some Questions Jews Ask," Nahum N. Glatzer (Ed.), Modern Jewish Thought: A Source Reader, New York: Schocken Bocks 1977.

Katz, Steven T. "The Holocaust: Jewish Theological Responses," Mircea Eliade (Ed.), The Encyclopedia of Religion, C. 6, New York: Macmillan 1987.

Katz, Steven T., "The Shoah," Daniel H. Frank ve Oliver Leamen (Ed.), History of Jewish Philosophy, C. 2, London: Routledge, 1997.

Otto, Rudolf, The Idea of the Holy: An Inquiry into the Non-Rational Factor in the Idea of the Divine and Its Relation to the Rational, Çev. John W. Harvey, Middlesex: Penguin Books, 1959.

Rubenstein, Richard ve John K. Roth, Approaches to Auschwitz: The Legacy of the Holocaust, London: SCM Press, 1987.

Sacks, Jonathan. Crisis and Covenant: Jewish Thought After the Holocaust, Manchester: Manchester University Press, 1992. 